UDK $374+004$

DOI 10.22363/2312-8631-2017-14-1-114-120

\title{
THE MAIN DIRECTIONS OF IMPLEMENTATION OF INFORMATION AND COMMUNICATION TECHNOLOGIES IN THE PROCESS OF LEARNING A FOREIGN LANGUAGE
}

\author{
G.A. Rizakhojayeva \\ International Kazakh-Turkish university of H.A. Yasavi \\ Sattarkhanov str., 29, Turkistan, Kazakhstan, 161200
}

\begin{abstract}
The main idea of modern education is intellectualization, globalization of the process of preparation of future specialists. The institutes of education can achieve this goal only through using innovative information and communication technologies. Application of ICT in the formation of professional communicative competence positively affect the quality of learning material, developing listening and speaking in real communicative level, develop writing and reading skills and promotes the development of various language skills of students of touristic specialties.

When you create a specific ICT-based teaching-learning environment and use active learning techniques, you significantly improve the level of professional communicative competence of students: special professional and personal knowledge; possession of specialized terminology to the extent necessary and sufficient for a complete and accurate description of the object of the profession; information culture; linguistic knowledge and skills; verbal communication skills and behavior; skills to independently analyze and vocational training situation and find the best way out of it; cognitive activity; communication skills associated with the development of the profession; ability to organize relationships with others; creative approach to business; skills to critically analyze the information already developed and quickly master the new challenge.
\end{abstract}

Key words: information and communication technologies, learning, foreign language, tourism specialists

Nowadays, one of the actual problems in A. Yasawi International Kazakh-Turkish University is training highly qualified specialists of international level and improve the effectiveness of the educational process at the credit-module system of training. The informatization of education and use of information and communication technologies in educational activity of future specialists on the basis of competence approach play an important role for organizing an efficient learning.

Informatization of the education system is regarded as a strategically important paradigm of the State Program of Development of Education of the Republic of Kazakhstan for 2011-2020, approved by the Decree of the President, the transition to e-learning is putted as first priority for provision of education system with highly qualified staff [1].

From our point of view, the introduction of ICT in the formation of professionalcommunicative competence of future specialists in the field od tourism in the learning process of a foreign language should be carried out in the following areas:

1. The use of certified programs, electronic textbook, electronic translators (Promt translator; Word Based Games). 
With the help of the program Word Based Games we can check vocabulary at every lesson. Create three types of transferable lexical exercises to establish correspondences between words or phrases (1. Jig Word - choice of conformity from the list (move with the mouse); 2. Match Word - input translation of the word, using the keyboard); 3. Speed Word - selection of appropriate in private cards ("hidden pair")).

2. Development of electronic teaching package (ETP) - a set of programs on all aspects of substantive work for the practical lessons in English.

ETP allows you to fully meet the needs of the teacher in the course of preparation and carrying out of employment. The structure ETP include: syllabus of the course; interactive presentations to practice self-control and pronunciation; interactive presentations on practical use of grammar; tests and test tasks; files background music lessons; interactive presentations on training and monitoring Listening (allow control and mutual control of training activities; video conversations and brief monologue statements with subtitles in English and Russian languages, and a selection of Internet resources for the studied subjects; detailed instructions for the plot-role-playing games and materials to them, the theme of possible projects, carrying out their instructions and materials.

3. Carrying out the plot-role-playing games in English via Internet - one of the most frequently used means of training and diagnostic knowledge through training. Consider the process of formation of information knowledge and skills of students on an example of working with educational material on "Tourism as a science and business. My future profession: a manager of tourism".

Identifying and sense of purpose is the first step in this process. Practice shows that through working with foreign language texts students find new information without considering such an important goal as the formation of lexical, grammatical and phonetic knowledge and skills of the target language.

In the second stage formulated the problem to be solved in the process of working with information. While working with the text "Tourism - science and business. My future profession: a manager of tourism", we identified the following problems:

1 . The selection, ordering and remembering new vocabulary.

2. Search, classification and analysis of grammatical phenomena.

3. Monitoring and adjustment of the acquired knowledge through reading and translation of texts.

4. The interpretation of the received information (drafting abstracts, annotations, summaries).

5. Organization of communication on a professional theme.

The third step in the process of formation of information skills is the choice of methods, forms and tools for the task.

Consider the case of organizing the lesson:

1. In carrying out the selection of new vocabulary, the student writes out new words in personal dictionary, organizes them by parts of speech and pronunciation of these words using foreign dictionaries in printed or electronic form. Using electronic dictionary has more advantages over the print. There are programs that allow you to get acquainted not only with the meaning of the word, but also hear its pronunciation. Memorizing vocabulary is performed by a variety of lexical exercises. 
2. Students analyze and systematize grammatical phenomena on the basis of previously learned grammatical material, on-example, choose sentences that predicate verb is in the passive voice. If it finds new grammatical construction, they study them in grammar reference, and then discuss this topic with the teacher (or vice versa). For the assimilation of acquired knowledge, students do grammar exercises and make their own proposals on the basis of new grammatical structures.

3. Reading and translation of the text allow to control of the acquired knowledge and skills and determine the success of the first two tasks.

4. The ability to interpret the information is based on education abstracting and annotation. The ability to abstract and annotate texts contributes to the formation of student's information style of thinking. In the process of abstracting (annotation), students learn to organize and roll information to choose the most important, critically rethink and evaluate what they read, to relate to the existing knowledge and on this basis to create new information, which they can later use in professional-directed speech utterances.

5. To organize a professional dialogue on the subject with the purpose of formation of communicative abilities of students are offered micro-situations for preparation of dialogues, plot-role-playing games, organize a conference or a "round table". At the end of the theme "Tourism - science and business. My future profession: a manager of tourism", we organize the plot-role-playing game "My future profession: a manager of tourism. Advantages and Disadvantages". The objectives are:

- to enable students to apply to the speech situation, close to reality, use vocabulary, phonetic and grammatical knowledge and skills in a foreign language;

- observe in the group the processes occurring during the discussion and collective decision-making in a situation of conflict of opinions;

- provide students with the opportunity to carry out pre-selection and to lay down their solutions to the issue under discussion. The time limit of the game: 45 minutes.

6. Record control text using the computer, self-test, and then test of the teacher. Thus, a bank of audio files is checked pronunciation of each student.

7. Listen to texts of various difficulties (Easy, Medium and Difficult) from the site www.esl-lab.com. Presents three types of exercise: pre-listening exercises (represented by words from the record on the basis of which it is necessary to predict the content record, down ideas and discuss them with a partner), self-audition (listen to the message, answer questions, check answers, listen to the message again, reading the source code, filling the gaps in the text); after listening exercise (Put yourself in the characters, use your own ideas to create a message. Describe the advantages and disadvantages of the communication in English).

8. Viewing video from the broadcasting system CNN http://www.cnn.com/video/ index.html, which is provided with transcripts of records. Typically, the transcript appears after $10-15$ hours after the program broadcast. Thereafter, the resulting record is listening and analyzes complex space.

9. Implementation of the project in English on different subjects (professional and meaningful, personal, etc.). One of the advantages of the use of new information technologies is shifting the focus from verbal methods of learning to search and creativity. Application of projects for teaching English provides the basis for the organization of 
independent work of students on the analysis and synthesis of the material with a wide use of individual and group forms of organization of educational process.

When you create a specific ICT-based teaching-learning environment and use active learning techniques, you significantly improve the level of professional communicative competence of students: special professional and personal knowledge; possession of specialized terminology to the extent necessary and sufficient for a complete and accurate description of the object of the profession; information culture; linguistic knowledge and skills; verbal communication skills and behavior; skills to independently analyze and vocational training situation and find the best way out of it; cognitive activity; communication skills associated with the development of the profession; ability to organize relationships with others; creative approach to business; skills to critically analyze the information already developed and quickly master the new challenge.

Application of ICT in the formation of professional communicative competence positively affect the quality of learning material, developing listening and speaking in real communicative level, develop writing and reading skills and promotes the development of various language skills of students of touristic specialties, allows:

- to conduct various kinds of dialogues: etiquette of dialogue, dialogue, conversation, professional dialogue, conversation, discourse with elements of monologue, etc.;

- to study and evaluation of reading;

- to enrich the vocabulary of students (both active and passive);

- revitalization of language and speech material, forming of stable language skills for all types of speech activity, the rapid exchange of information, ideas, plans for partners interested in the subject, using a foreign language as a means of communication between partners;

- individualization of the learning process in the organization of group and pair of projects in which each student has to define their own role;

- formation of students' culture of dialogue, communication skills, which involves students into concisely and clearly articulating their own thoughts (oral and written), develop tolerance to the opinion of the partners, the ability to listen and respect the opinion of the partner, the ability to lead the discussion, arguments to prove their point of view;

- development of skills of self-education, self-acquisition and improvement of knowledge of a foreign language on the basis of research methods (working with a dictionary, including electronic and traditional language reference, remote databases containing information cultural, regional, geographic, nature).

It is important to note that the solution of problems of formation of professional communicative competence is achieved through the presentation of the material several training tools, each of which has its didactic possibilities. They are:

- publications, containing all the necessary materials that do not require further treatment to students of educational information;

- electronic publications, the possibility of operational changes and long-distance transmission by e-mail;

- computer training system in the form of e-books, software and methodical complex, training programs;

- Didactic audio and video shown on computer; 
- computer networks containing various kinds of information and a set of computers connected by communications channels.

Among the professional difficulties of the teacher in the formation of professional communicative competence today are precisely in the field of ICT applications:

- Insufficient number of teaching materials use of educational software in a foreign language;

- The poor quality of teaching materials;

- Insufficient number of computers;

- Insufficient number of software;

- The low level of information culture of students;

- Insufficient level of information culture of lecturers;

- Difficulties in the conducting the lessons;

- Lack of time in the classroom;

- Lack of knowledge of the possibilities of using information and communication technologies in teaching foreign languages.

On the basis of the difficulties identified by the use of ICT in professional activity are the following criteria influencing the effectiveness of formation of professional communicative competence of students of touristic specialties:

- An overall strategy of formation of professional and communicative competence of students;

- The use of active forms and methods of teaching (role-playing games, telecommunication projects, master classes and others);

- Own cognitive activity of students;

- The use of ICT in education;

- Qualitative methodological and technical support;

- The right combination of traditional teaching and learning with the use of ICT.

Interest in lessons can be enhanced by the skillful use of ICT, which can be successfully applied in the conventional system and as a supplement. Analyzing the opportunities of ICT for the implementation of information exchange between the actors of the educational process, it became clear didactic potential of learning English - the possibility of organizing an active communicative activity of learners based telecommunications interpersonal communication, both with the teacher and with each other.

Actual Survey of students of the Yasawi International Kazakh-Turkish University, the department "Management and Tourism", 2 and 3 courses of specialty "Tourism 5B090200", according to the degree of importance of the use of ICT in teaching to enhance interest in learning a foreign language was conducted. The results of the survey showed the following, the students' interest in learning a foreign language greatly increased, when in the classroom new technologies were used, there is a low level of interest in traditional lessons. So, from 52 surveyed students 43 students $(81 \%)$, noted that the use of new technologies greatly enhance the interest in learning a foreign language, 9 respondents (17\%) expressed indifference due to the style of lessons and 3 students $(2 \%)$ were against of the use of ICT in the classroom (Fig. 1). It is noteworthy, that the last 3 students explained the reluctance to the use of ICT in the classroom, as they don't have any interest in learning foreign language. 


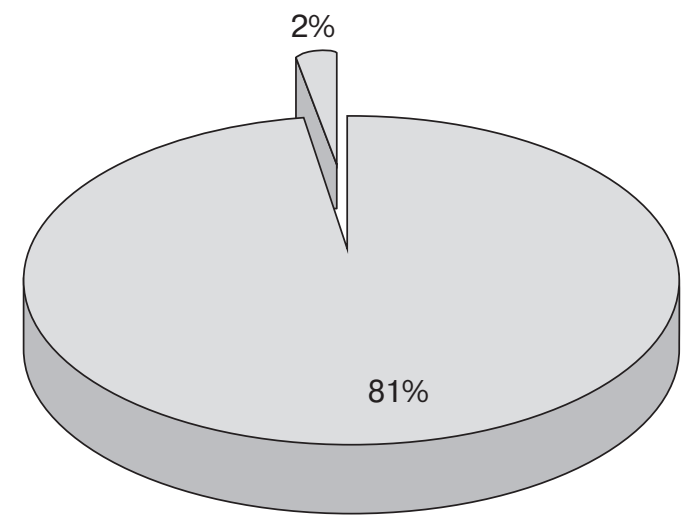

Fig. 1. Percentage distribution of answers of future specialists of tourism, on the degree of importance of ICT in the teaching process to enhance interest in learning a foreign language

The unity and the relationship used in the activity of the teacher training facilities related to the implementation of the principle of the integrated use of ICT orients the teacher on the best use of each session of verbal, visual and practical methods.

As the conclusion it should be noted, that having an arsenal of active methods and means of pedagogical diagnostics of professional communicative competence in foreign language teaching allows students of tourist professions develop a system of formation of professional communicative competence of the future specialists.

\section{REFERENCES}

[1] Gosudarstvennaja programma razvitija obrazovanija Respubliki Kazahstan na 2011-2020 gody [The project of the state program of education development of the Republic of Kazakhstan on 2011-2020 years]. URL: http:// egov.kz/

[2] Milbrud R.P., Maksimova I.R. Sovremennye konceptual'nye principy obuchenija inostrannogojazyka [Modern conceptual principles of the communicative teaching foreign languages]. Inostrannyj jazyk v shkole [Foreign languages at school]. 2000. No. 4. Pp. 9-15.

[3] Zaharova I.G. Informacionnye tehnologii v obrazovanii [Information technologies in education]. M.: Akademija, 2005. Pp. 22.

[4] Panina G.S., Vavilov L.N. Sovremennye sposoby aktivizacii obuchenija [Modern methods of activization of training]: uchebnoe posobie. M.: Akademija, 2006. $176 \mathrm{p}$.

(C) Rizakhojayeva G.A., 2017

Article history:

Received: 10 November 2016

Accepted: 30 November 2016

For citation:

Rizakhojayeva G.A. The main directions of the implementation of information and communication technologies in the process of learning a foreign language // RUDN Journal of Informatization Education. 2017. 14 (1). 114-120.

\section{Bio Note:}

Rizakhodzhayeva Gulnara Abdumazhitovna, PhD doctoral candidate of the International KazakhTurkish university named after H.A. Yassavi (Turkestan, Kazakhstan)

Contact information: e-mail: gulnara_rizahodja@mail.ru. 


\title{
ОСНОВНЫЕ НАПРАВЛЕНИЯ ВНЕДРЕНИЯ ИНФОРМАЦИОННЫХ И КОММУНИКАЦИОННЫХ ТЕХНОЛОГИЙ В ПРОЦЕСС ОБУЧЕНИЯ ИНОСТРАННОМУ ЯЗЫКУ
}

\author{
Г.А. Ризаходжаева \\ Международный казахско-турецкий университет им. Х.А. Яссави \\ ул. Б. Саттарханова 29, Туркестан, Казахстан, 161200
}

Основополагающей идеей современного образования является интеллектуализация, глобализация процесса подготовки будущих специалистов. Институты образования могут достигнуть этих целей только через использования инновационных информационных и коммуникационных технологий (ИКТ). Следует отметить, что внедрение ИКТ в процесс формирования коммуникативной компетенции специалиста позитивно влияют на качество изучаемого материала, развивают навыки говорения и аудирования на реальном коммуникационном уровне, развивают навыки чтения и письма и способствуют проявлению множества других языковых навыков студентов, будущих специалистов в области туризма. При создании атмосферы обучения на основе ИКТ и посредством использования активных методов обучения и внедрения различных технологий обучения значительно возрастает уровень профессиональной коммуникативной компетенции студентов: специальные персональные и профессиональные знания, развивается информационная культура; лингвистические знания и умения; навыки вербальной коммуникации и правильного поведения при общении; умение правильно анализировать ситуацию и своевременно принимать те или иные решения; креативный подход в решении поставленных задач; способность критического анализа информации.

Ключевые слова: информационные и коммуникационные технологии, обучение, иностранный язык, туризм, специалист

\section{История статьи: \\ Дата поступления в редакцию: 10 ноября 2016 \\ Дата принятия к печати: 30 ноября 2016}

\section{Для цитирования:}

Ризаходжаева Г.А. Основные направления внедрения информационных и коммуникационных технологий в процесс обучения иностранному языку // Вестник Российского университета дружбы народов. Серия «Информатизащия образования». 2017. Т. 14. № 1. С. 114-120.

\section{Сведения об авторе:}

Ризаходжсаева Гулнара Абдумажитовна, $\mathrm{PhD}$ докторант Международного казахско-турецкого университета им. Х.А. Яссави (Туркестан, Казахстан)

Контактная информация: e-mail: gulnara_rizahodja@mail.ru. 